\title{
A estabilidade e a efetividade da preferência partidária no Brasil
}

\author{
The stability and effectiveness of partisan preferences \\ in Brazil
}

Boa parte da literatura da ciência política brasileira sobre comportamento eleitoral tem se dedicado ao exame da influência da preferência partidária sobre o voto para presidente. ${ }^{1}$ Em sua maioria, os estudos mais atuais procuram verificar em que medida a preferência do eleitor por um ou outro partido tende a se associar à sua escolha de candidato. O objeto é de interesse capital para estudiosos da democracia brasileira, uma vez que a conexão entre eleitores e partidos é vista como um importante indicador da institucionalização do sistema partidário (Dalton e Wattenberg, 2000; Dalton, 2007).

Uma das estratégias de análise mais comuns do impacto da preferência partidária é o exame de correlações entre essa variável e o voto, geralmente medidos por meio de pesquisas de opinião coletadas no mesmo ponto do tempo (Carreirão e Kinzo, 2004; Carreirão, 2007; Nicolau, 2007). Esse tipo de análise tem se tornado cada vez mais comum, com a disseminação do uso de técnicas estatísticas e a disponibilidade crescente de dados de pesquisa de opinião para os cientistas políticos brasileiros. A partir de tais análises,

É doutorando em Ciência Política pela Universidade de Vanderbilt (Nashville, Estados Unidos) e mestre em Ciência Política pela Universidade Federal de Minas Gerais (Belo Horizonte, MG). E-mail: frederico.b.pereira@Vanderbilt.Edu.

Este artigo foi desenvolvido a partir de um capítulo de minha dissertação de mestrado defendida no Departamento de Ciência Política da Universidade Federal de Minas Gerais (UFMG) em 2010. Agradeço enormemente a Lucio Rennó por ceder o banco de dados utilizado. Sou também grato aos comentários de Fábio Wanderley Reis, Mônica Mata Machado de Castro e Mario Fuks. Os erros e limitações do artigo são de minha responsabilidade. 
algumas conclusões sobre a dinâmica do partidarismo no eleitorado brasileiro se estabelecem. Em primeiro lugar, os dados mostram que a proporção de eleitores brasileiros que declara ter preferência por algum partido é baixa se comparada às de democracias mais avançadas (Samuels, 2006). Mais ainda, por conta da curta duração (comparativamente falando) e da complexidade do sistema partidário brasileiro, os eleitores menos escolarizados e informados tendem a ser menos partidários do que os mais informados e escolarizados (Kinzo, 2005). Nesse sentido, além de servir como base do voto de uma parcela minoritária do eleitorado, os partidos não servem de referência para a escolha das massas menos politicamente sofisticadas.

No entanto, apesar desse acúmulo de conhecimento sobre o partidarismo no atual sistema partidário brasileiro, ainda há perguntas a serem respondidas. Até que ponto é possível assumir que os eleitores que declaram ter preferência partidária em pesquisas de opinião realmente possuem uma orientação substantiva em relação ao partido que preferem? Dito de outro modo, até que ponto o partidarismo é mesmo uma orientação forte entre os eleitores que o manifestam? Muito embora pareça não haver trabalhos que examinem empiricamente essa questão entre os estudos mais recentes, duas autoras já especularam sobre possíveis respostas. Balbachevsky (1992) defendeu que, mesmo constituindo um grupo reduzido do eleitorado, a parcela de indivíduos que manifestam preferência partidária teria, sim, uma orientação forte em relação aos partidos. Por outro lado, Castro (1994) argumentou que a preferência partidária de grande parte dos eleitores que a manifestam seria uma orientação instável, em boa medida afetada por fatores de curto prazo, como a campanha e os próprios candidatos.

$\mathrm{O}$ presente artigo pretende reagir ao debate instaurado entre as duas perspectivas acima. O principal objetivo da discussão e das análises a seguir é tentar responder se a preferência partidária é uma orientação política estável e efetiva no Brasil. Para tanto, o artigo se utiliza de dados de pesquisa de opinião em painel, ou seja, entrevistas realizadas ao longo do tempo com os mesmos indivíduos. A pesquisa utilizada aqui se chama "The dynamics of political attitude formation in a milieu of multiple weak parties: a contextsensitive analysis of voting behavior in two Brazilian cities" (Baker et al., 2006). A pesquisa realizou ondas de entrevistas em abril/maio, agosto/setembro e outubro de 2002, maio de 2004, julho e outubro de 2006 nas cidades brasileiras de Juiz de Fora (MG) e Caxias do Sul (RS). Uma amostra de 2500 
entrevistados foi gerada em cada cidade na onda de abril/maio de 2002 . O procedimento de múltiplos estágios foi utilizado com amostragem aleatória no nível da vizinhança, seguido do setor censitário, depois domicílio e, por fim, pessoas. Ao final da primeira onda de entrevistas, $74 \%$ do total das pessoas contatadas foram entrevistadas, sendo que a mesma porcentagem foi obtida em setembro de 2002 . Dessas, $84 \%$ foram entrevistadas na terceira onda de outubro de 2002. No presente artigo são analisadas as informações relativas às ondas de abril e outubro de 2002, e também de maio de $2004^{2}$. Ainda que os dados não representem todo o eleitorado brasileiro, acredita-se que os resultados encontrados aqui não sejam específicos das duas cidades analisadas, e tampouco do período específico de tempo coberto.

A próxima seção discute o conceito e a teorização sobre a preferência partidária desde suas primeiras formulações por parte de estudiosos do partidarismo nos Estados Unidos. Nessa discussão, destaca-se a importância de dois elementos principais no desenvolvimento e na mudança da preferência partidária do indivíduo: a socialização política e a avaliação retrospectiva do desempenho dos partidos. Em seguida, a segunda seção traça a dinâmica da preferência partidária nas diferentes configurações do sistema político brasileiro ao longo do tempo. Argumenta-se que as proporções de eleitores partidários, bem como sua distribuição na população, podem ser entendidas a partir da teorização existente sobre a dinâmica da preferência partidária, tal como discutida na primeira seção do artigo. Finalmente, os dados da pesquisa de painel são analisados para se verificar até que ponto a preferência partidária é uma orientação estável e efetiva entre o grupo de eleitores partidários no Brasil.

\section{Formação e dinâmica da preferência partidária}

Uma das primeiras e mais importantes formulações visando definir a preferência partidária dos eleitores foi proposta pela escola de Michigan. Em vez de simplesmente falarem em atitude ou preferência partidária, Campbell e seus colegas optaram pelo termo "identificação" para se referirem à orientação afetiva em relação a importantes "grupos-objeto" do ambiente (Campbell et al., 1960, p. 121). Os autores enfatizaram que o que chamaram de "identificação" com os partidos seria necessariamente uma orientação

O programa R (<http://www.r-project.org/>) foi utilizado nas análises estatísticas. 
afetiva forte e estável, o que a qualificaria como distinta das demais opiniões e preferências políticas. Em obra anterior, mas de orientação teórica semelhante, a posição de Campbell e seus colegas fica clara:

A presente análise da identificação partidária se baseia na suposição de que os dois partidos servem como grupos de referência para uma parcela significativa das pessoas do país. Em outras palavras, assume-se que muitas dessas pessoas se associam psicologicamente com um dos partidos, e que tal identificação possui relações previsíveis com suas percepções, avaliações e ações. Espera-se que essas relações se dêem em áreas da experiência que são relevantes para as atividades político-partidárias (Campbell et al., 1954, p. 90, tradução nossa).

Campbell e seus colegas observaram em suas análises que a identificação partidária no eleitorado estadunidense seria estável e altamente associada ao voto dos eleitores ao longo do tempo. A identificação partidária seria, nesse sentido, anterior às preferências em relação a outros objetos do ambiente eleitoral, inclusive a própria preferência pelo candidato a presidente. Ademais, os autores dedicaram um capítulo inteiro de seu livro a examinar como a conexão afetiva dos eleitores com o partido seria algo passado de geração para geração, principalmente na socialização dos cidadãos em ambientes familiares longamente comprometidos com a clivagem partidária existente (Campbell et al., 1960; Converse, 1969). Diante desse quadro, a identificação partidária foi vista por grande parte dos estudiosos estadunidenses como o "motor imóvel" do comportamento político.

Além de ser concebida como uma adesão quase mecânica a um dos partidos nos Estados Unidos, a preferência partidária também ganha destaque pela capacidade que teria de estruturar as opiniões e outras preferências dos eleitores sobre política. Brady e Sniderman (1985), por exemplo, mostraram que os eleitores estadunidenses seriam em sua maioria capazes de estimar as posições dos principais grupos políticos nos assuntos relevantes com base no que chamaram de "heurística do afeto", ou seja, com base no gosto que teriam por cada partido. O eleitor, dessa forma, seria capaz de inferir a posição de democratas e republicanos quanto a importantes dimensões temáticas da política dos Estados Unidos a partir de sua própria posição e de sua inclinação a gostar ou desgostar de tais grupos. Druckman (2001) 
mostrou que os chamados "efeitos de enquadramento", isto é, a mudança das preferências dos indivíduos com base em controles nos enunciados da escolha, tenderia a diminuir quando houvesse a menção ao nome de algum dos dois grandes partidos da política dos Estados Unidos. Esses são apenas exemplos pontuais de uma vasta produção que atesta o quanto o partidarismo pode ser visto como uma atitude política estável e efetiva nas escolhas políticas dos estadunidenses.

Alguns autores, por outro lado, não naturalizaram de tal maneira a força que a identificação partidária poderia ter entre os eleitores estadunidenses. É possível que o estudo de Fiorina (1981) seja um dos mais importantes nesse sentido. Fiorina mostrou que durante períodos de crises econômicas e guerras nos quais se envolveu o país em meados do século XX, teria se verificado maior propensão dos eleitores a abandonarem sua preferência partidária se o seu partido predileto se encontrasse no poder. Do ponto de vista teórico, Fiorina pretende justamente fornecer um quadro analítico que dê conta tanto da mudança quanto da continuidade da identificação partidária nos Estados Unidos. Para ele, ainda que a identificação partidária seja uma orientação afetiva duradoura e herdada da socialização política, ela pode oscilar se o desempenho do partido preferido - ou qualquer outra modificação significativa no ambiente eleitoral - contrariar enormemente as expectativas de seus eleitores. Em outras palavras, o que a escola de Michigan chamou de "identificação" com os partidos não parece ser em nada diferente do que a psicologia social estadunidense considera como sendo uma atitude, uma orientação afetiva positiva ou negativa em relação um objeto, a qual se forma e se modifica de acordo com os estímulos que o indivíduo recebe do ambiente (Krosnick e Rahn, 1994, p. 279).

Com a contribuição do trabalho de Fiorina, é possível concluir que a atitude ou preferência partidária possui uma dinâmica de formação e mudança que depende da interação entre fatores relacionados aos estímulos do ambiente e atributos individuais. Essa constatação implica que não se pode naturalizar a preferência partidária como sendo uma atitude estável, ou mesmo defini-la em função de propriedades que ela adquire em um ambiente político específico. Nem todo partidarismo é estável e efetivo.

Se a preferência partidária depende de fatores ambientais e de atributos individuais, então é de se esperar que, mesmo onde ela pareça ser mais estável e efetiva, também seja possível verificar variações sistemáticas em 
sua dinâmica. Alguns estudos estadunidenses já mostraram e discutiram exatamente essa variação, e vale a pena examiná-los por um momento.

No que se refere às variações ambientais, o trabalho de Brody (1991) é sem dúvida uma referência importante. Para verificar como o ambiente afeta a dinâmica da preferência partidária, Brody se dedicou a comparar as preferências partidárias dos cidadãos estadunidenses entre períodos eleitorais e não eleitorais. Como analisava um mesmo sistema político, Brody utilizou as variações sistemáticas no ambiente eleitoral estadunidense ao longo do tempo. $\mathrm{O}$ autor lançou mão de dados de séries temporais para mostrar que a identificação partidária nos Estados Unidos apresentaria frequentes flutuações em intervalos muito curtos de tempo, intervalos ainda menores do que aqueles que haviam sido analisados por Fiorina e pelos autores da escola de Michigan. Escândalos políticos, temas político-partidários salientes, eleições e diversos outros fatores bombardeariam o eleitorado com estímulos favoráveis e desfavoráveis aos atuais posicionamentos, e fariam com que as taxas de identificação partidária flutuassem mais do que grande parte dos analistas supunha até então. Nesse sentido, a preferência partidária não seria apenas causadora das percepções e opiniões políticas, mas poderia ser ela mesma afetada por essas orientações e percepções (Brody, 1991, p. 204).

Do ponto de vista da variação individual da dinâmica da identificação partidária, o trabalho de Howell (1986) fornece evidências de que a sofisticação política teria papel crucial na explicação. Por meio da análise de dados de painel, a autora mostrou que seria relativamente comum que eleitores de menor sofisticação política manifestassem preferência por um partido apenas depois de terem escolhido o candidato, o que indicaria que tais eleitores teriam sua preferência partidária afetada pela escolha do candidato, e não o contrário. Assim, a identificação partidária tenderia a ser uma atitude menos estável justamente entre os menos politicamente sofisticados. Essa consideração remete à proposição recorrentemente defendida pela tese da sofisticação política: eleitores menos sofisticados teriam atitudes políticas menos estáveis e efetivas e estariam mais sujeitos a mudá-las ao sabor de estímulos mais circunstanciais, como o gosto pelos candidatos, por exemplo (Zaller, 1992; Zaller e Feldman, 1992). No caso estudado por Howell, tudo indica que uma preferência partidária propriamente "eleitoral” emergiu circunstancialmente, e que provavelmente foi a atitude mais forte em relação ao candidato do partido que fez com que o eleitor decidisse sua identificação com tal partido. 
Em suma, o que se pretendeu argumentar até este ponto é que a chamada "identificação partidária" é uma atitude política sujeita a mudanças como qualquer outra orientação. Apesar da ênfase exagerada da escola de Michigan nos componentes mais estáveis dessa orientação, há uma ampla literatura posterior que demonstra que tal preferência oscilaria de forma sistemática ao longo do tempo e entre segmentos do eleitorado estadunidense. Enquanto o cidadão se encontra imerso na influência familiar e recebe estímulos favoráveis a determinado partido, ele se declara favorável a esse partido. Como essa preferência foi reforçada continuamente ao longo do tempo, ele tende a mantê-la e a levá-la em conta quando pensa sobre política. No entanto, diante de circunstâncias nas quais recebe estímulos fortes e recorrentes que vão de encontro à sua preferência, especialmente em meio a crises econômicas e escândalos políticos, esse eleitor se vê momentaneamente inclinado a abandonar seu partido e até mesmo a votar no candidato do partido opositor. É importante ter em conta, todavia, que não é preciso que essa literatura posterior conceba a preferência partidária de maneira inteiramente distinta da escola de Michigan. Ainda se verificam taxas relativamente altas de partidarismo nos Estados Unidos, e o voto continua a ser em boa medida afetado por essa variável, ainda que existam controvérsias aparentemente intermináveis a respeito (Wattenberg, 1996; Craig, 1985; Bartels, 2000; Kaufman et al., 2008). A preferência partidária estável e efetiva não é de natureza conceitual inteiramente distinta da preferência partidária fraca e volátil.

É a partir do enquadramento discutido até aqui que as próximas seções deste artigo abordam a preferência partidária no Brasil. O objetivo principal da próxima seção é apresentar as principais discussões sobre a preferência partidária no país e problematizar seu papel como determinante do voto no sistema multipartidário atual. $\mathrm{O}$ argumento principal a ser desenvolvido e examinado empiricamente mais à frente é o de que a complexidade do sistema partidário brasileiro atual tornaria mais agudo o efeito da sofisticação política sobre a efetividade e a estabilidade das preferências partidárias dos eleitores. $\mathrm{O}$ resultado seria que a preferência partidária, vista nos Estados Unidos como um atalho eficiente até mesmo para eleitores menos sofisticados tomarem sua decisão, seria um determinante efetivo do voto apenas entre uma parcela minoritária de eleitores politicamente sofisticados no Brasil. 


\section{A preferência partidária no Brasil}

As oscilações mais visíveis da distribuição das preferências partidárias no Brasil acompanharam as mudanças drásticas ocorridas na formatação do sistema partidário do país. Nos últimos setenta anos, três arranjos partidários distintos foram observados: o período multipartidário pré-1964, o período do bipartidarismo do regime militar e o retorno ao multipartidarismo nos anos 1980. Do ponto de vista da oscilação das taxas gerais da preferência partidária, essas mudanças no sistema partidário brasileiro se refletem em alterações sistemáticas na distribuição das atitudes em relação aos partidos. Uma literatura relativamente extensa já deu conta do assunto, e a análise do conjunto dos achados permite observar o quanto o ambiente eleitoral afeta as atitudes dos eleitores em relação aos partidos.

O trabalho de Lavareda (1991) ajuda a compreender a distribuição da preferência partidária durante o período pré-1964. O objetivo do autor em um ponto de seu trabalho é mostrar que o eleitorado do período teria apresentado taxas relativamente altas de adesão aos partidos políticos da época, chegando a uma média de $60 \%$ em algumas capitais brasileiras (os três principais partidos eram PTB, PSD e UDN). O autor analisa dados de pesquisas eleitorais da época e mostra que haveria taxas consideráveis de manifestação de preferências partidárias, as quais seriam até mesmo maiores do que as que o sistema multipartidário atual apresenta. Pelos resultados que Lavareda apresenta, é possível ressaltar que a combinação de alguns fatores poderia causar esses níveis elevados de partidarismo, se comparados ao período mais atual. Em primeiro lugar, apesar de haver uma multiplicidade de partidos, apenas os três maiores tendiam a dividir o eleitorado e disputar os principais cargos políticos no país, o que representaria uma enorme simplificação do quadro partidário. Além disso, outro fator ambiental seria crucial para serem elevadas tais taxas: a presença de líderes políticos capazes de atrair as massas para seus partidos.

O ponto parece muito claro em um exame mais atento da tabela oferecida por Lavareda a respeito da preferência partidária em algumas das principais capitais do país no período (Lavareda, 1991, p. 135). Nota-se claramente, por exemplo, que o PSP só atinge uma taxa de preferência partidária substantiva em São Paulo, onde coincidentemente desponta Ademar de Barros como uma figura política carismática de extremo apelo em certos setores da sociedade. A única capital onde o PSD atinge uma taxa de preferência partidária tão elevada quanto PTB e UDN é em Belo Horizonte, cidade fortemente influenciada pela 
presença do ex-prefeito e ex-presidente Juscelino Kubitschek. A UDN atinge sua taxa recorde no Rio de Janeiro, onde Carlos Lacerda contribui para tornar o partido mais próximo do eleitorado. O PTB, por sua vez, atinge a taxa mais alta em Porto Alegre, Rio Grande do Sul, estado de Getúlio Vargas, político mais proeminente do período. Em suma, a preferência partidária no período parecia acompanhar a presença de figuras políticas fortes, e não o contrário.

Além desses fatores, que têm a ver com a estrutura dos estímulos políticos disponíveis ao eleitorado, vale mencionar que os analfabetos não participavam dos pleitos, e é justamente esse segmento do eleitorado que tende a apresentar as menores taxas de adesão aos partidos (Kinzo, 2005). Haveria assim um efeito de seleção pelo sistema de voto, uma vez que os indivíduos menos propensos a desenvolver a preferência partidária não eram legalmente autorizados a votar ${ }^{3}$.

A literatura a respeito do período seguinte é provavelmente a que trata de forma mais sistemática das preferências partidárias. Diante de taxas ainda mais elevadas de adesão aos partidos do que no período anterior, chegando a atingir cerca de $70 \%$ dos entrevistados nas cidades analisadas, Lamounier $(1975,1978,1980)$ e Reis $(1975,1978)$ trataram de se perguntar o que produziria esse quadro e quais as suas consequências para o desenvolvimento político do país no período ${ }^{4}$. Os autores se perguntaram até que ponto as altas taxas de preferência pelo $\mathrm{MDB}$, principalmente no meio urbano, se constituiriam de vínculos psicológicos baseados na adesão informada aos projetos do partido, ou se essas taxas representariam apenas vínculos circunstanciais causados pela particular configuração do sistema partidário e pela possibilidade de se canalizar no MDB a manifestação de insatisfações difusas em relação ao regime vigente. Reis (1983) oferece uma resposta ao questionamento acima, favorável ao efeito que teria a adoção do sistema bipartidário. Sobre ela, o autor afirma:

Ela redundou, com efeito, numa simplificação drástica das opções e do universo defrontado pelo eleitor ao tomar sua decisão eleitoral. Do ponto de vista da consciência política dos estratos populares, tal simplificação se superpôs “convenientemente" ao simplismo das percepções e opiniões políticas (Reis, 1983, p. 74-75).

É também possível que as taxas de preferência partidária fossem superestimadas na pesquisa pelo fato de que ela inclui apenas capitais. É provável que os eleitores das zonas rurais fossem os menos partidários, especialmente em um contexto em que a divisão urbano-rural era ainda mais desigual do que é atualmente.

4 Os estudos de Lamounier e Reis analisam quatro cidades, duas paulistas e duas mineiras: São Paulo (Lamounier, 1975, 1980), Presidente Prudente (Lamounier, 1978), Belo Horizonte (Reis, 1975) e Juiz de Fora (Reis, 1978). 
Fica claro no trecho acima que a configuração do sistema político naquele momento teria atuado no sentido de facilitar as escolhas dos eleitores mais alheios ao processo político-eleitoral. Em seus estudos, Reis e Lamounier apresentaram evidências da existência de apreensões desiguais do universo político eleitoral entre os diferentes estratos da população. Os eleitores menos escolarizados teriam uma apreensão muito mais simplificada das informações políticas, de modo que seu comportamento, ainda que guiado pela identificação com o MDB, seria sustentado por considerações muito distintas daquelas que conformariam os comportamentos dos eleitores mais escolarizados e ideológicos. O segmento menos escolarizado do eleitorado possuía a imagem do MDB como o "partido do povo", e tal imagem seria descolada de conteúdos mais refinados de natureza ideológica.

Sendo essa adesão ao MDB um tanto circunstancial e desigual entre segmentos mais e menos politicamente sofisticados do eleitorado da época, o que esperar, então, da identificação com os partidos em um eventual contexto posterior de sistema partidário mais complexo no Brasil? A resposta de Lamounier é clara no que se refere às preocupações dos autores com relação à estabilidade e à efetividade das atitudes partidárias em um ambiente político complexo e mutável como o brasileiro:

É nosso propósito mostrar que a votação do MDB em São Paulo baseia-se em alinhamentos extraordinariamente estáveis no que diz respeito às áreas sócio-econômicas da cidade; mas também que essa estabilidade se sustenta em conteúdos subjetivos bastante rarefeitos, o que nos obriga a reconhecer um alto grau de incerteza diante de uma eventual reformulação do quadro partidário (Lamounier, 1980, p. 15).

É precisamente com esse quadro de incerteza que a literatura do período seguinte se depara com o sistema multipartidário posterior ao regime militar. Alguns dos principais estudos sobre o tema apresentam dados com taxas de partidarismo entre 1989 e 2002 que teriam variado de $40 \%$ a 50\% do eleitorado (Carreirão e Kinzo, 2004, p. 141; Kinzo, 2005, p. 68; Samuels, 2006, p. 4). Esse resultado é inferior ao dos períodos anteriores e se refere a um sistema com uma quantidade muito maior de partidos.

Além disso, Kinzo também mostrou que o novo arranjo partidário seria mais politicamente desigual. A análise da autora verificou que os eleitores que declaram possuir preferência partidária são justamente os mais politicamente sofisticados (Kinzo, 2005, p. 73). Segundo Kinzo, isso seria resultado do fato 
de que o sistema partidário teria se tornado mais complexo, fazendo com que os menos sofisticados encontrem mais dificuldade em manifestar adesão pelos partidos. Diferentemente do que ocorria no período militar, no qual os segmentos menos escolarizados do meio urbano conseguiam identificar o partido predileto, o novo sistema partidário dificultaria a adesão partidária do eleitorado como um todo, e mais ainda para os eleitores menos sofisticados.

Entretanto, grande parte da literatura mais recente que utiliza a preferência partidária nas análises não problematiza o efeito que a sofisticação política teria sobre a efetividade e a estabilidade da variável no ambiente multipartidário. Parte dessa literatura simplesmente trata a preferência partidária como um determinante do voto para presidente (Carreirão e Kinzo, 2004; Carreirão, 2007; Nicolau, 2007). Em geral, os estudos desse tipo analisam a associação entre identificação partidária e voto por meio da correlação agregada para todo o eleitorado, implicitamente assumindo que a preferência pelo partido seria um antecedente da preferência pelo candidato. Trata-se de uma orientação teórica claramente distinta da que permeava os estudos de Reis e Lamounier durante a década de 1970. De acordo com esses autores, ainda que boa parte do eleitorado menos escolarizado manifestasse preferência por um dos partidos, isso não asseguraria que tal identificação seria guiada por considerações políticas consistentes que a tornariam mais estável e efetiva.

Balbachevsky parece ter ido ao outro extremo do debate. A autora questionou a postura dos estudos sobre o período autoritário afirmando que ela seria "conservadora" e defenderia a incapacidade do eleitorado de massa de se conectar com os partidos políticos. Para a autora, "a identificação partidária agora, tanto quanto no período autoritário, recorta na população o conjunto de eleitores disponíveis para a participação política, para quem a competição partidária alcança um significado subjetivo próprio" (Balbachevsky, 1992, p. 140). Com isso, Balbachevsky parece defender que, dentre a parcela minoritária de eleitores partidários no atual sistema multipartidário brasileiro, não haveria nenhuma diferença interna no que se refere aos níveis de apreensão da política. Nesse sentido, haveria uma e apenas uma "identificação partidária”, a qual seria estável e efetiva independentemente do nível de sofisticação política ou escolaridade do eleitor que a manifesta.

Por outro lado, Castro (1994) argumentou que, mesmo que se verifique a associação entre preferência partidária e voto, não se pode afirmar que se trata de uma atitude política forte entre o eleitorado brasileiro. Segundo a autora, 
Não se pode considerar esse fator como o único e mais importante responsável pela definição do voto dos eleitores, porque grande parte do eleitorado simplesmente não tem, nos últimos anos, preferência partidária estável, e porque os dados sugerem que, pelo menos parte das identificações com os partidos políticos, quando existem, manifesta-se somente no processo eleitoral, talvez orientadas pelas escolhas de candidatos. Se as preferências partidárias dos eleitores não estão baseadas na percepção da coincidência entre as suas opiniões e as propostas dos partidos, e se, no Brasil, elas não têm sido estáveis, elas podem decorrer, transitoriamente, da decisão de votar em certo candidato (Castro, 1994, p. 168-169).

Na perspectiva defendida por Castro, seria de se esperar que no sistema multipartidário brasileiro grande parte dos eleitores que manifestam terem preferência partidária esteja simplesmente a declarar possuir uma atitude que na verdade é fraca e volátil. Essa postura diverge totalmente da que defendeu Balbachevsky, e instaura um debate que desde os estudos da década de 1970 parecia estar à margem da discussão sobre a psicologia do voto no Brasil.

A próxima seção pretende abordar as questões acima por meio da análise de dados empíricos. As perspectivas de Balbachevsky e Castro serão confrontadas para, afinal, se verificar se é possível entender que a chamada “identificação partidária” opera da mesma maneira para todos os eleitores e pode ser vista como um determinante forte do voto para presidente no Brasil. Vale adiantar que, levando-se em conta as características que tornam o sistema partidário brasileiro extremamente complexo e as evidências no que diz respeito à desigualdade de sofisticação política entre os eleitores do país, parece pouco plausível supor que o simples ato de manifestar preferência partidária denote a existência de uma atitude estável e efetiva. Nesse sentido, a perspectiva defendida aqui é essencialmente a mesma que Castro aplica em suas observações sobre a associação entre partidarismo e voto na atual configuração do sistema partidário brasileiro.

\section{"Dois petismos"}

As próximas duas seções pretendem examinar a força da preferência partidária como determinante do voto no Brasil a partir de sua estabilidade e efetividade. Os dados utilizados no presente trabalho permitem examinar em alguma medida tanto a estabilidade quanto a efetividade da preferência partidária em Juiz de Fora e Caxias do Sul. A Tabela 1 mostra a distribuição da variável em outubro de 2002. O PT apresenta uma taxa média de cerca de 30\% 
da amostra total, mas a adesão varia de aproximadamente $25 \%$ em Caxias do Sul a quase $40 \%$ em Juiz de Fora. Já a proporção de respondentes que preferem o PSDB parece ser um pouco menor do que os $5 \%$ convencionais de outras pesquisas, e não passa de $2 \%$ na amostra total, sendo que é de 1,5\% em Caxias e de 2,5\% em Juiz de Fora. Já a proporção de preferência declarada pelo PMDB oscila de 15\% em Caxias a 5\% em Juiz de Fora, sendo que a proporção total se assemelha à distribuição nacional, sendo de aproximadamente $10 \%$ dos respondentes. No geral, a proporção de respondentes que declara gostar de algum partido nesse período de outubro também se assemelha à distribuição que convencionalmente se encontra em pesquisas pós-eleitorais, sendo cerca de 50\% (Carreirão e Kinzo, 2004, p. 141; Kinzo, 2005, p. 68).

\section{Tabela 1. Distribuição da preferência partidária em outubro}

\begin{tabular}{c|c|c|c}
\hline partido & $\begin{array}{c}\text { Juiz de Fora } \\
\mathrm{n}=2594\end{array}$ & $\begin{array}{c}\text { Caxias do Sul } \\
\mathrm{n}=2528\end{array}$ & $\begin{array}{c}\text { amostra total } \\
\mathrm{n}=5122\end{array}$ \\
\hline PMDB & $5,13 \%$ & $15,19 \%$ & $10,09 \%$ \\
\hline PSDB & $2,51 \%$ & $1,54 \%$ & $2,03 \%$ \\
\hline PT & $39,75 \%$ & $24,05 \%$ & $32,00 \%$ \\
\hline outros partidos & $4,86 \%$ & $5,14 \%$ & $5,06 \%$ \\
\hline nenhum & $47,75 \%$ & $54,08 \%$ & $50,82 \%$ \\
\hline
\end{tabular}

Fonte: Baker et al. (2006)

As análises feitas a partir daqui focalizam especificamente os respondentes que declaram preferirem o PT. Essa restrição se justifica por duas razões. Primeiro, como se está abordando a preferência partidária como um determinante do voto em eleições presidenciais, a preferência pelo PMDB não tem lugar na análise, já que o partido não lançou candidato a presidente naquela eleição. Em segundo lugar, a proporção de eleitores que preferem o PSDB e os outros partidos que lançaram candidatos é muito baixa, e não se justifica sua análise tanto por questões metodológicas, já que o reduzido número de casos torna baixíssima a confiabilidade dos resultados, quanto por razões substantivas, já que se estaria falando de menos de $3 \%$ dos respondentes da pesquisa. Sendo assim, a análise da preferência partidária no Brasil passa em ampla medida pela análise mesma do petismo, já que a identificação com esse partido é o que faz com que a taxa de preferência partidária do país atinja patamares razoáveis se comparada às de outros países (Samuels, 2006, p. 1). 
O exame de pesquisas feitas para amostras distintas ao longo do tempo tem mostrado que a taxa de preferência pelo PT se elevou consideravelmente ao longo da década de 1990 (Carreirão e Kinzo, 2004; Kinzo, 2005, Samuels, 2006), e atingiu proporções mais estáveis em torno dos 30\% do eleitorado após 2002. Todavia, esse tipo de análise apenas permite que o analista veja que o nível geral de preferência pelo PT se mantém relativamente estável ao longo do tempo, mas não autoriza dizer que essa adesão seja estável no nível individual. O formato de painel dos dados analisados aqui possibilita o exame da estabilidade da preferência pelo PT no nível dos indivíduos. Como já se mencionou, uma onda de entrevistas ocorreu nos meses de março e abril, antes do início do Horário Gratuito de Propaganda Eleitoral (HGPE). Outra onda de entrevistas foi realizada em outubro, depois do HGPE, entre o primeiro e o segundo turno da eleição ${ }^{5}$. A Tabela 2 mostra que a estabilidade do petismo nas pesquisas de séries temporais é, em boa medida, um artifício produzido pela agregação dos dados:

Tabela 2. Cruzamento entre o número de petistas entre abril e outubro para toda a amostra

\begin{tabular}{c|c|c|c|c}
\hline \multicolumn{2}{c|}{} & \multicolumn{2}{|c}{ abril } & \\
\hline \multirow{2}{*}{ outubro } & não petista & petista & total \\
\cline { 2 - 5 } & não petista & 2147 & 190 & 2337 \\
\hline \multirow{2}{*}{} & petista & 488 & 618 & 1106 \\
\hline
\end{tabular}

Fonte: Dados obtidos a partir de Baker et al. (2006)

Como parece claro, a proporção de petistas é maior em outubro (32\%) em relação a abril (23\%). Nesse ponto, a análise da Tabela 2 corrobora parcialmente as expectativas de Castro, uma vez que mostra que parte da preferência partidária emerge no período eleitoral. Mas há outra evidência na tabela que parece mostrar a fragilidade das preferências partidárias ao longo do tempo. Se a Tabela 2 é lida no sentido inverso ao que mandam os manuais de metodologia, ou seja, contando-se as porcentagens horizontalmente, no sentido da variável dependente (a preferência pelo PT em outubro), nota-se que 488 (45\%) dos 1106 petistas de outubro não se declaravam petistas em abril. Dessa forma, uma flutuação que, no nível agregado, parece cobrir menos de um terço

Uma onda de entrevistas também foi realizada em setembro, antes do início do HGPE. No entanto, nessa onda não foi perguntado aos entrevistados sobre sua preferência partidária, o que inviabiliza sua utilização para os interesses do presente artigo. 
dos petistas (9\% no salto de $23 \%$ para $32 \%$ ) se mostra bem maior quando é vista do ponto de vista individual, atingindo quase metade dos eleitores que preferem o PT em outubro. Por um lado, o resultado fundamenta a desconfiança de Castro (1994) em relação à força da associação entre preferência partidária e voto. Por outro, há também uma proporção de petistas que parece ter preferência estável, tal como propôs Balbachevsky (1992).

Se alguém declara ter preferência pelo PT, supõe-se que venha a declarar voto pelo candidato do partido na eleição presidencial. No entanto, a suposição de que essa associação representa uma relação de causalidade na qual o partidarismo leva ao voto é justamente o que se questiona no trabalho de Castro (1994, p. 168-169). A alternativa proposta pela autora sugere basicamente que a atitude em relação ao partido não seria mais estável e efetiva do que a preferência pelo candidato, e sim o contrário. Assim, a preferência partidária não poderia anteceder o voto, e sim ser antecedida por ele. Os dados também possibilitaram um exame parcial dessa hipótese. Para se testar até que ponto a preferência por Lula antecede a preferência pelo PT em outubro, dois modelos de regressão logística foram especificados para explicar o voto em Lula em outubro em dois subgrupos da amostra: o grupo de petistas estáveis, que se chamou de "petistas de abril", e o grupo de preferência instável, os "petistas de outubro". A principal variável independente nos dois modelos é a preferência por Lula em abril. Se a preferência por Lula em abril tiver um efeito positivo substancial na preferência por Lula em outubro entre aqueles petistas que não preferiam o PT em abril, pode-se dizer que é então a preferência por Lula que antecede a preferência pelo PT. Entre os "petistas de abril" (os estáveis), espera-se que a preferência por Lula em abril tenha impacto na preferência por Lula em outubro, o que não permite qualquer inferência a respeito de ordem causal. Os modelos incluem variáveis de controle como a avaliação da economia ${ }^{7}$, a autolocalização ideológica ${ }^{8}$, e também as variáveis

Esses termos foram escolhidos em clara alusão aos "May voters" e "September-to-November voters", do clássico estudo de Lazarsfeld e seus colegas (1965, p. 52).

A avaliação sociotrópica se refere à avaliação da economia de um modo geral, enquanto a avaliação pessoal se refere apenas à situação do respondente. O fraseado da primeira era o seguinte:"Falando em geral do país nos últimos 12 meses, você acha que a situação econômica melhorou muito, melhorou pouco, ficou igual, piorou pouco ou piorou muito?". O fraseado da pergunta sobre avaliação pessoal era:"Com relação à sua situação econômica pessoal, nos últimos 12 meses você acha que ela melhorou muito, melhorou pouco, ficou igual, piorou pouco ou piorou muito?". As opções de resposta variam do "melhorou muito" (igual a 0) ao "piorou muito" (igual a 4). Essas variáveis foram medidas em outubro.

8 A questão oferecia cinco opções de resposta (muito esquerda, esquerda, centro, direita e muito direita). Nos modelos apresentados aqui a variável é binária, indicando se o respondente escolhe "esquerda" 
sócio-demográficas (renda familiar, escolaridade, raça, sexo e a cidade do respondente $)^{9}$. A Tabela 3 apresenta os resultados dos modelos:

Tabela 3. Regressões logísticas binárias sobre o voto em Lula em outubro (amostra total)

\begin{tabular}{|c|c|c|}
\hline \multirow{3}{*}{ variáveis independentes } & "petistas de outubro" & "petistas de abril" \\
\hline & coeficiente & coeficiente \\
\hline & (erro padrão) & (erro padrão) \\
\hline \multirow{2}{*}{ intercepto } & 0,71 & 0,35 \\
\hline & $(0,70)$ & $(0,79)$ \\
\hline \multirow{2}{*}{ votou em Lula em abril (não=0) } & 0,45 & $1,09 * * *$ \\
\hline & $(0,34)$ & $(0,30)$ \\
\hline \multirow{2}{*}{ esquerda (não=0) } & $-0,000$ & $-0,00$ \\
\hline & $(0,30)$ & $(0,34)$ \\
\hline \multirow{2}{*}{ avaliação sociotrópica da economia } & 0,16 & 0,21 \\
\hline & $(0,13)$ & $(0,13)$ \\
\hline \multirow{2}{*}{ avaliação pessoal da economia } & 0,06 & 0,20 \\
\hline & $(0,14)$ & $(0,15)$ \\
\hline \multirow{2}{*}{ renda } & $-0,00$ & 0,00 \\
\hline & $(0,00)$ & $(0,00)$ \\
\hline \multirow{2}{*}{ escolaridade } & 0,03 & 0,04 \\
\hline & $(0,05)$ & $(0,05)$ \\
\hline \multirow{2}{*}{ branco (não=0) } & $-0,41$ & $-0,91^{* * *}$ \\
\hline & $(0,28)$ & $(0,35)$ \\
\hline \multirow{2}{*}{ sexo (mulher=0) } & 0,23 & $-0,20$ \\
\hline & $(0,28)$ & $(0,30)$ \\
\hline \multirow{2}{*}{ cidade (Juiz de Fora=0) } & $-0,18$ & 0,03 \\
\hline & $(0,32)$ & $(0,32)$ \\
\hline $\mathrm{n}$ & 436 & 543 \\
\hline
\end{tabular}

***Estatisticamente significativo a 0,01 .

Fonte: Dados obtidos a partir de Baker et al. (2006)

A Tabela 3 mostra que, quando se toma o intervalo de tempo entre abril e outubro, não se pode dizer que a preferência por Lula antecede a preferência pelo PT entre os "petistas de outubro". O efeito do voto em Lula em abril sobre o voto em Lula em outubro é baixo e não é estatisticamente significativo, indicando que a preferência por Lula é quase tão instável quanto a preferência pelo PT no intervalo de tempo analisado. Assim, ainda que não seja possível 
constatar a direção de causalidade entre as duas preferências no sentido proposto por Castro (já que ainda assim é possível que a preferência por Lula tenha se formado antes da preferência pelo PT no intervalo de tempo entre abril e outubro), pode-se dizer que, em boa medida, as duas preferências se formaram apenas no período mais próximo da eleição, haja vista que a proporção de petistas instáveis que declara votar em Lula salta de $24 \%$ em abril para $85 \%$ em outubro. Cerca de $90 \%$ dos petistas de abril declaram votar em Lula em outubro, sendo que quase $60 \%$ já o preferiam em abril.

A análise acima favorece a tese de Castro de que parte substancial da preferência partidária pelo PT emerge no período eleitoral e provavelmente apenas em virtude dele. Apenas isso já torna questionável a reivindicação de Balbachevsky de que a "identificação partidária" seria forte independentemente das desigualdades no eleitorado. Entretanto, ainda é necessário mostrar em que medida os grupos com maior e menor estabilidade na preferência pelo PT apresentam perfis distintos no que se refere a atributos individuais teoricamente relevantes.

A Tabela 4 apresenta dois modelos de regressão logística binária que estimam a probabilidade de um respondente que se declara petista na onda de outubro também ter se declarado petista na onda de abril, isto é, a probabilidade de que um petista tenha uma preferência estável ao longo do tempo pelo partido em questão. O primeiro modelo examina apenas o efeito da sofisticação política e da escolaridade, controlados pela cidade do respondente ${ }^{10}$. O segundo modelo da tabela especifica que outros atributos medidos no nível individual podem também afetar a probabilidade de o respondente petista ter uma preferência estável pelo $\mathrm{PT}^{11}$. Os resultados seguem abaixo ${ }^{12}$ :

10 A sofisticação política corresponde à quantidade e integração das informações que um indivíduo possui sobre política (Luskin, 1990, p. 332; Neuman, 1981, 1237). A medida utilizada aqui vem de seis questões de informação política perguntadas em abril. Utilizou-se a teoria de resposta ao item (Birnbaum, 1968; Baker, 2001; Osterlind, 1983) para ponderar a influência de cada item no construto final com base na dificuldade e no poder de discriminação da questão. O construto final foi re-escalado para variar entre 0 e 6 , tal como se fosse um simples somatório do número de itens respondidos corretamente.

11 A variável "possui pai petista" no segundo modelo é binária. As variáveis de "exposição à TV"e "exposição a outros meios" vêm de perguntas sobre a quantidade de vezes por semana que o respondente alega ter contato com cada meio de comunicação. Essas duas variáveis constituem simplesmente o somatório das respostas positivas. As variáveis de "exposição em conversas"e "associativismo"também foram medidas por baterias de perguntas com escalas do tipo Likert sobre a frequência de realização da atividade (nunca, raramente, algumas vezes ou sempre). A variável de "participação eleitoral"vem de uma bateria de cinco perguntas sobre diferentes tipos de participação dos respondentes em campanhas de eleições anteriores. Essas três últimas variáveis foram tratadas por teoria de resposta ao item e re-escaladas para variarem entre os mesmos valores de seu somatório.

12 Modelos anteriores foram especificados controlando-se por outras variáveis de perfil socioeconômico e 
Tabela 4. Regressões logísticas binárias tendo como variável dependente 0 "tipo de petismo" (petista de outubro $=0$ ) para toda a amostra

\begin{tabular}{|c|c|c|}
\hline \multirow{3}{*}{ variáveis independentes } & modelo 1 & modelo 2 \\
\hline & coeficiente & coeficiente \\
\hline & (erro padrão) & (erro padrão) \\
\hline \multirow{2}{*}{ intercepto } & $-1,27^{* * *}$ & $-1,45^{* * *}$ \\
\hline & $(0,21)$ & $(0,28)$ \\
\hline \multirow{2}{*}{ escolaridade } & $0,07^{* * *}$ & 0,03 \\
\hline & $(0,02)$ & $(0,02)$ \\
\hline \multirow{2}{*}{ sofisticação política } & $0,16^{* * *}$ & $0,09^{* *}$ \\
\hline & $(0,04)$ & $(0,04)$ \\
\hline \multirow{2}{*}{ exposiç̧ão em conversas } & \multirow{2}{*}{-} & 0,12 \\
\hline & & $(0,13)$ \\
\hline \multirow{2}{*}{ participação eleitoral } & \multirow{2}{*}{-} & 0,19 \\
\hline & & $(0,11)$ \\
\hline \multirow{2}{*}{ associativismo } & \multirow{2}{*}{-} & 0,06 \\
\hline & & $(0,14)$ \\
\hline \multirow{2}{*}{ exposição à TV } & \multirow{2}{*}{-} & $-0,00$ \\
\hline & & $(0,02)$ \\
\hline \multirow{2}{*}{ exposição a jornais e revistas } & \multirow{2}{*}{-} & 0,02 \\
\hline & & $(0,02)$ \\
\hline \multirow{2}{*}{ esquerda (não = 0) } & \multirow{2}{*}{-} & $0,80^{* * *}$ \\
\hline & & $(0,14)$ \\
\hline \multirow{2}{*}{ possui pai petista (não = 0) } & \multirow{2}{*}{ - } & $0,98^{* * *}$ \\
\hline & & $(0,26)$ \\
\hline \multirow{2}{*}{ cidade (Juiz de Fora = 0) } & $1,13^{* * *}$ & $1,05^{* * *}$ \\
\hline & $(0,14)$ & $(0,15)$ \\
\hline $\mathrm{n}$ & \multicolumn{2}{|c|}{1104} \\
\hline
\end{tabular}

** estatisticamente significativo a 0,05

*** estatisticamente significativo a 0,01

Fonte: Dados obtidos a partir de Baker et al. (2006)

O Modelo 1 indica que os "petistas de abril" tendem a ser mais escolarizados e mais politicamente sofisticados do que os "petistas de outubro". Também os respondentes de Caxias do Sul têm maior probabilidade de serem

demográfico como a renda familiar, o sexo, a raça e a idade. Apenas a escolaridade teve efeito relevante sobre a probabilidade de se possuir preferência estável pelo PT, e por isso as demais variáveis foram descartadas dos modelos finais. Todas as variáveis independentes desse modelo foram coletadas em abril. 
do grupo que possui a preferência estável pelo PT. Apenas para ilustrar, um indivíduo que atinge o máximo de pontos na escala de sofisticação política (6 pontos) apresenta $24 \%$ a mais de probabilidade de pertencer ao grupo dos petistas estáveis, comparado ao respondente que obtém o mínimo no escore de sofisticação (nenhum ponto). A escolaridade apresenta um efeito que não chega a ter a metade da magnitude do efeito da sofisticação política.

O Modelo 2 inclui outros atributos individuais à equação do Modelo 1. Em geral, essas variáveis representam atributos de um perfil de indivíduo cuja socialização política foi mais intensa. A variável sobre a preferência do pai pelo PT busca captar diretamente esse tipo perfil. Os resultados mostram que petistas que também se declaram de esquerda e cujo pai é ou era petista têm probabilidade muito maior de serem petistas estáveis. Além disso, os "petistas de abril" tendem também a conversar com mais frequência sobre política e são indivíduos mais participativos em campanhas eleitorais. Nota-se também que a inclusão dessas novas variáveis faz com que o efeito da sofisticação caia pela metade, o que é esperado, uma vez que essas variáveis compartilham variância e estão todas ligadas ao processo de socialização política. $\mathrm{O}$ efeito da escolaridade cai muito e perde importância frente às demais variáveis independentes do modelo. As variáveis de associativismo e exposição aos meios de comunicação apresentam efeitos quase nulos.

As análises acima permitem concluir que, do ponto de vista da estabilidade do partidarismo, existem diferenças cruciais entre indivíduos mais e menos politizados que declaram preferir um partido (no caso, o PT). A Tabela 5 permite finalmente avaliar a magnitude do efeito das variáveis mais fortemente associadas aos perfis no Modelo 2 acima $^{13}$. Vale lembrar que o modelo da Tabela 4 é um modelo de regressão aditivo simples, sendo que os valores encontrados para as probabilidades na Tabela 5 resultam apenas da adição das probabilidades dadas por cada estimativa da regressão ${ }^{14}$ :

\footnotetext{
3 A simulação de valores de interesse permite visualizar com mais clareza a magnitude dos efeitos de cada variável, além de propiciar a simulação da probabilidade para indivíduos com perfis determinados pelo analista (King et al., 2000; Imai et al, 2008, 2009). Essa técnica simula distribuições para os parâmetros estimados assumindo que tais distribuições são normais. A partir disso, o programa calcula os valores preditos para cada amostra simulada e utiliza a distribuição desses valores preditos para gerar uma estimativa (média) e seu erro (erro padrão da média).

${ }_{14}$ Qualquer aparente efeito de interação nas probabilidades da Tabela 6 resulta simplesmente do chamado "efeito de compressão"(Berry et al., 2010) comum aos modelos que têm variáveis dependentes binárias (Logit e Probit).
} 
Tabela 5. Simulação de valores de interesse do modelo logístico da Tabela 4 para toda a amostra

\begin{tabular}{|c|c|c|c|c|c|}
\hline $\begin{array}{c}\text { sofisticação } \\
\text { política }\end{array}$ & $\begin{array}{c}\text { exposição em } \\
\text { conversas }\end{array}$ & $\begin{array}{c}\text { participação } \\
\text { eleitoral }\end{array}$ & esquerda & pai petista & $\begin{array}{c}\text { probabilidade de } \\
\text { ser "petista de abril" }\end{array}$ \\
\hline \multirow{16}{*}{ nenhuma $(=0)$} & \multirow{8}{*}{ nunca $(=0)$} & \multirow{4}{*}{ nenhuma $(=0)$} & \multirow{2}{*}{ não } & não & $32 \%$ \\
\hline & & & & $\operatorname{sim}$ & $55 \%$ \\
\hline & & & \multirow{2}{*}{$\operatorname{sim}$} & não & $50 \%$ \\
\hline & & & & $\operatorname{sim}$ & $73 \%$ \\
\hline & & \multirow{4}{*}{ todas $(=3)$} & \multirow{2}{*}{ não } & não & $45 \%$ \\
\hline & & & & $\operatorname{sim}$ & $68 \%$ \\
\hline & & & \multirow{2}{*}{$\operatorname{sim}$} & não & $64 \%$ \\
\hline & & & & sim & $82 \%$ \\
\hline & \multirow{8}{*}{$\begin{array}{l}\text { frequentemente } \\
\qquad(=3)\end{array}$} & \multirow{4}{*}{ nenhuma $(=0)$} & \multirow{2}{*}{ não } & não & $40 \%$ \\
\hline & & & & $\operatorname{sim}$ & $63 \%$ \\
\hline & & & \multirow{2}{*}{$\operatorname{sim}$} & não & $59 \%$ \\
\hline & & & & $\operatorname{sim}$ & $78 \%$ \\
\hline & & \multirow{4}{*}{ todas $(=3)$} & \multirow{2}{*}{ não } & não & $53 \%$ \\
\hline & & & & $\operatorname{sim}$ & $75 \%$ \\
\hline & & & \multirow{2}{*}{$\operatorname{sim}$} & não & $71 \%$ \\
\hline & & & & $\operatorname{sim}$ & $86 \%$ \\
\hline \multirow{16}{*}{ média (=3) } & \multirow{8}{*}{ nunca $(=0)$} & \multirow{4}{*}{ nenhuma $(=0)$} & \multirow{2}{*}{ não } & não & $38 \%$ \\
\hline & & & & $\operatorname{sim}$ & $61 \%$ \\
\hline & & & \multirow{2}{*}{$\operatorname{sim}$} & não & $57 \%$ \\
\hline & & & & sim & $78 \%$ \\
\hline & & \multirow{4}{*}{ todas $(=3)$} & \multirow{2}{*}{ não } & não & $51 \%$ \\
\hline & & & & $\operatorname{sim}$ & $73 \%$ \\
\hline & & & $\operatorname{sim}$ & não & $69 \%$ \\
\hline & & & SIIII & $\operatorname{sim}$ & $85 \%$ \\
\hline & & & ñ̃ & não & $46 \%$ \\
\hline & & nenhuma $(-0)$ & 1100 & $\operatorname{sim}$ & $68 \%$ \\
\hline & & remula $(=0)$ & $\operatorname{sim}$ & não & $65 \%$ \\
\hline & frequentemente & & sim & $\operatorname{sim}$ & $83 \%$ \\
\hline & $(=3)$ & & מี̃ & não & $59 \%$ \\
\hline & & $\operatorname{tad} a s(-3)$ & Ildo & sim & $79 \%$ \\
\hline & & $\operatorname{touds}(=0)$ & sim & não & $76 \%$ \\
\hline & & & SIIII & $\operatorname{sim}$ & $89 \%$ \\
\hline & & & ถว̃ก & não & $43 \%$ \\
\hline & & nenhuma $(-0)$ & Hav & $\operatorname{sim}$ & $67 \%$ \\
\hline & & & sim & não & $63 \%$ \\
\hline & nupga $(-0)$ & & SIIII & $\operatorname{sim}$ & $82 \%$ \\
\hline & nunca $(=0)$ & & מ̃̃ & não & $58 \%$ \\
\hline & & tod $(2)$ & IIdo & sim & $77 \%$ \\
\hline & & todas $(=3)$ & sim & não & $74 \%$ \\
\hline muito -6$)$ & & & SilII & sim & $88 \%$ \\
\hline multa $(=0)$ & & & חว̃ก & não & $52 \%$ \\
\hline & & nonhum $(-0)$ & IIdo & $\operatorname{sim}$ & $74 \%$ \\
\hline & & remuna $(=0)$ & $\operatorname{sim}$ & não & $70 \%$ \\
\hline & frequentemente & & simI & sim & $86 \%$ \\
\hline & $(=3)$ & & מ̃̃ & não & $65 \%$ \\
\hline & & $\operatorname{tad} a s(-3)$ & 1100 & sim & $82 \%$ \\
\hline & & todas $(=3)$ & sim & não & $81 \%$ \\
\hline & & & SIIII & sim & $91 \%$ \\
\hline
\end{tabular}


A simulação na Tabela 5 mostra que as variáveis inseridas respondem por grande parte da variabilidade na probabilidade de que os petistas sejam estáveis. Possuir um pai petista aumenta em média $22 \%$ a probabilidade de se ter preferência estável pelo PT. Ser de esquerda aumenta essa probabilidade em cerca de $18 \%$. Um petista que declara conversar frequentemente sobre política tem $8 \%$ a mais de probabilidade de ser um petista estável do que aquele que declara nunca conversar sobre o assunto. A sofisticação apresenta um efeito baixo com esses novos controles (apenas $1 \%$ a mais para cada ponto a mais na escala), e o efeito da participação eleitoral é um pouco maior (cerca de $2 \%$ a mais para cada ponto aumentado na escala de 0 a 3 ). No geral, o conjunto desses fatores altera bastante a probabilidade de um petista possuir preferência estável, o que indica que existem atributos individuais sistematicamente associados com a estabilidade do partidarismo.

\section{Os efeitos dos "dois petismos"}

O passo final das análises consiste em verificar se existem diferenças no que se refere à efetividade da preferência partidária entre os grupos de petistas mais e menos estáveis. Como se mencionou anteriormente, os dois grupos votam em proporções muito parecidas no candidato do PT para a presidência em outubro. No entanto, pela análise da estabilidade, parece complicado inferir que é o petismo que causa o voto, pelo menos entre os chamados "petistas de outubro".

Existem outras maneiras de se testar a efetividade da preferência partidária que não envolvem o exame do voto para presidente. Outros comportamentos do eleitor podem ser baseados em sua preferência por um dos partidos. Esta seção pretende examinar dois resultados do petismo manifestado em outubro: o voto no PT em outros cargos da disputa eleitoral e o próprio petismo manifestado quase dois anos depois, em 2004. É de se esperar que os "petistas de abril", isto é, os petistas mais estáveis, tendam a votar mais no PT para cargos diferentes do presidente, e que também se manifestem petistas em maior proporção em 2004.

A Tabela 6 a seguir apresenta os resultados de outros quatro modelos de regressão logística binária que testam as proposições enunciadas acima. Os quatro modelos têm quatro variáveis binárias diferentes: o voto no PT para governador do estado, o voto no PT (no candidato ou na legenda) 
para senador, o voto na legenda do PT para deputado estadual ${ }^{15}$, e o petismo manifestado em 2004. Os modelos incluem as mesmas variáveis de controle dos modelos na Tabela 3. Nos modelos para o voto em outros cargos, toda a amostra de respondentes é analisada. No modelo para o petismo em 2004, apenas os respondentes que se declaravam petistas em outubro de 2002 são comparados. As duas principais variáveis independentes indicam se o respondente é um "petista de abril" ou um "petista de outubro". A categoria de referência nos modelos para o voto nos outros cargos corresponde a todos os demais respondentes ${ }^{16}$. No modelo para o petismo em 2004, a categoria de referência são os "petistas de outubro". A expectativa inicial nos três primeiros modelos é que os "petistas de abril" e os "petistas de outubro" votem mais no PT nos outros cargos do que os demais respondentes. Ademais, espera-se que os "petistas de abril" votem mais no PT nos outros cargos do que os "petistas de outubro". Para o modelo do petismo em 2004, espera-se que os petistas estáveis de 2002 (os “petistas de abril”) sejam os mais propensos a ainda serem petistas dois anos depois.

15 Não havia a informação sobre o candidato específico no qual os respondentes votaram.

${ }^{16}$ Por conta dos objetivos da análise, e também por uma questão de simplicidade na apresentação dos resultados, não se diferenciou esse grupo de não petistas no que se refere a suas preferências por outros partidos. 
Tabela 6. Regressões logísticas binárias para toda a amostra

\begin{tabular}{|c|c|c|c|c|}
\hline \multirow{3}{*}{$\begin{array}{c}\text { variáveis } \\
\text { independentes }\end{array}$} & $\begin{array}{c}\text { voto no PT para } \\
\text { governador }\end{array}$ & $\begin{array}{l}\text { voto no PT para } \\
\text { senador }\end{array}$ & $\begin{array}{l}\text { voto na legenda do } \\
\text { PT para deputado }\end{array}$ & $\begin{array}{l}\text { petismo } \\
\text { em } 2004\end{array}$ \\
\hline & coeficiente & coeficiente & coeficiente & coeficiente \\
\hline & (erro padrão) & (erro padrão) & (erro padrão) & (erro padrão) \\
\hline \multirow[t]{2}{*}{ intercepto } & $-3,00^{* * *}$ & $-2,62^{* * *}$ & $-3,90 * * *$ & $-0,78$ \\
\hline & $(0,26)$ & $(0,23)$ & $(0,42)$ & $(0,44)$ \\
\hline \multirow[t]{2}{*}{ "petista de abril" } & $2,34^{* * *}$ & $1,77^{* * *}$ & $1,96^{* * *}$ & $0,97^{* * *}$ \\
\hline & $(0,12)$ & $(0,12)$ & $(0,19)$ & $(0,17)$ \\
\hline \multirow[t]{2}{*}{ "petista de outubro" } & $1,77^{* * * *}$ & $1,29 * * *$ & $1,57^{* * *}$ & - \\
\hline & $(0,12)$ & $(0,12)$ & $(0,21)$ & - \\
\hline \multirow[t]{2}{*}{ esquerda (não=0) } & $0,72^{* * *}$ & $0,68^{* * *}$ & $0,39 * *$ & 0,30 \\
\hline & $(0,10)$ & $(0,10)$ & $(0,17)$ & $(0,17)$ \\
\hline \multirow[t]{2}{*}{$\begin{array}{c}\text { avaliação sociotrópica } \\
\text { da economia }\end{array}$} & $0,12^{* *}$ & $0,13^{* * *}$ & 0,11 & -0.01 \\
\hline & $(0,05)$ & $(0,04)$ & $(0,08)$ & $(0,08)$ \\
\hline \multirow[t]{2}{*}{$\begin{array}{c}\text { avaliação pessoal } \\
\text { da economia }\end{array}$} & $0,12^{* * *}$ & $0,12^{* * *}$ & 0,06 & $-0,11$ \\
\hline & $(0,05)$ & $(0,04)$ & $(0,08)$ & $(0,08)$ \\
\hline \multirow[t]{2}{*}{ renda } & 0,00 & 0,00 & 0,00 & 0,00 \\
\hline & 0,00 & $(0,00)$ & $(0,00)$ & $(0,00)$ \\
\hline \multirow[t]{2}{*}{ escolaridade } & $0,04^{* * *}$ & $0,05^{* * *}$ & $-0,01$ & $0,06^{* *}$ \\
\hline & $(0,01)$ & $(0,01)$ & $(0,02)$ & $(0,03)$ \\
\hline \multirow[t]{2}{*}{ branco (não=0) } & $-0,03$ & 0,01 & $-0,25$ & -0.29 \\
\hline & $(0,10)$ & $(0,09)$ & $(0,16)$ & $(0,17)$ \\
\hline \multirow[t]{2}{*}{ sexo (mulher=0) } & 0,05 & $-0,05$ & 0,09 & $-0,03$ \\
\hline & $(0,10)$ & $(0,09)$ & $(0,15)$ & $(0,16)$ \\
\hline \multirow[t]{2}{*}{ cidade (Juiz de Fora=0) } & $-0,20^{* *}$ & $0,24^{* * *}$ & $-0,31$ & 0,32 \\
\hline & $(0,10)$ & $(0,09)$ & $(0,17)$ & $(0,18)$ \\
\hline $\mathrm{n}$ & 2987 & 2987 & 2987 & 680 \\
\hline
\end{tabular}

*** Estatisticamente significativo a 0,01

** Estatisticamente significativo a 0,05

Fonte: Dados obtidos a partir de Baker et al. (2006)

Os resultados acima parecem corroborar as hipóteses sobre os dois petismos. Como se nota, os "petistas de abril" tendem a votar mais no PT para outros cargos do que os "petistas de outubro", e ambos os grupos o fazem com maior probabilidade do que os demais respondentes. Também se vê que os "petistas de abril" são os mais propensos a manifestarem preferência 
pelo PT em 2004. No entanto, os coeficientes dos modelos não permitem uma comparação mais substantiva a respeito das magnitudes das diferenças. Para examinar melhor tais diferenças, os gráficos a seguir apresentam as probabilidades preditas a partir dos modelos da Tabela 6, e permitem comparar os subgrupos de eleitores da maneira como interessa à análise ${ }^{17}$ :

Gráfico 1. Probabilidade de votar no PT para o governo estadual (amostra total)

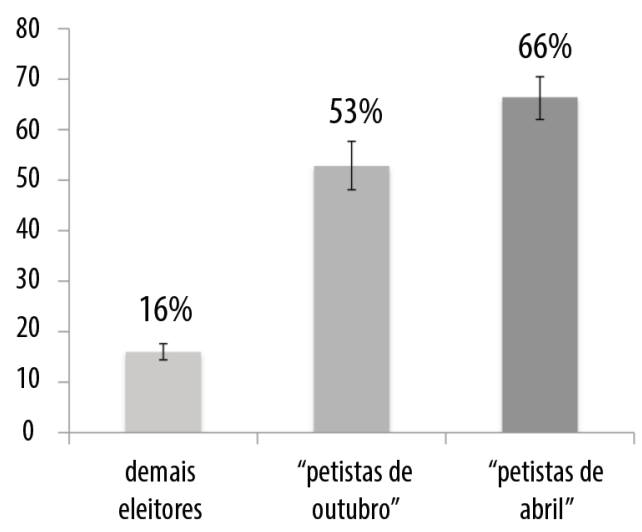

Fonte: Dados obtidos a partir de Baker et al. (2006)

Gráfico 2. Probabilidade de votar no PT para o senado (amostra total)

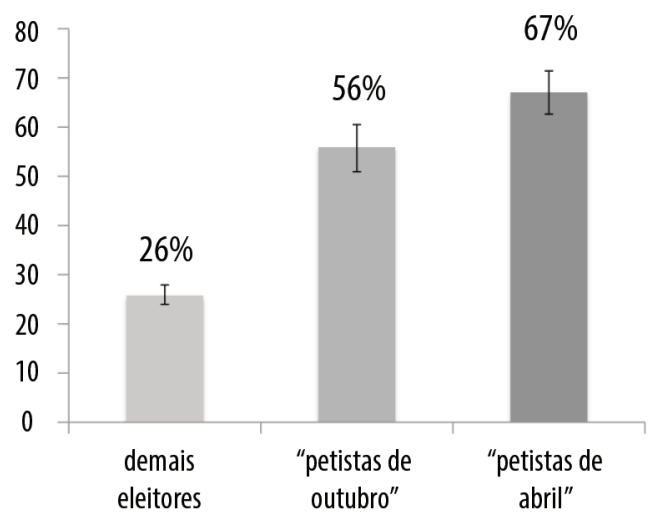

Fonte: Dados obtidos a partir de Baker et al. (2006)

$\overline{17}$ As probabilidades dos gráficos 1 a 4 foram geradas com base na simulação de valores de interesse. 
Gráfico 3. Probabilidade de votar na legenda do PT para deputado estadual (amostra total)

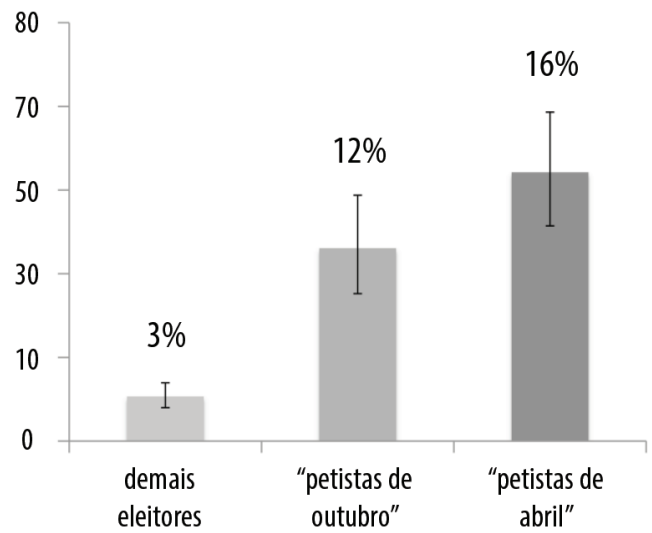

Fonte: Dados obtidos a partir de Baker et al. (2006)

Gráfico 4. Probabilidade de ser petista em 2004 (amostra total)

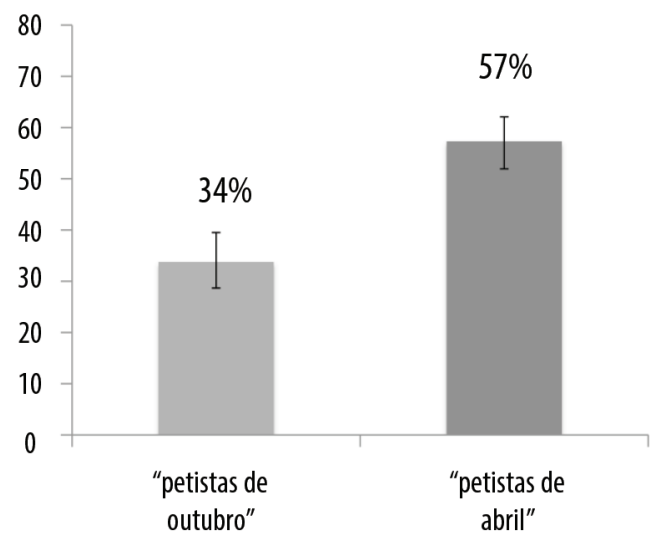

Fonte: Dados obtidos a partir de Baker et al. (2006)

Os gráficos 1 e 2 mostra que a diferença entre as chances de "petistas de abril" e "petistas de outubro" votarem no PT para os cargos de governador e senador é substancial. Para o voto na legenda, a diferença não é tão grande, e não chega a ser estatisticamente significativa. Já para o petismo em 2004, há uma diferença de mais de 20 pontos percentuais entre os dois grupos, 
revelando que, enquanto a maioria dos "petistas de abril" ainda é petista em 2004, apenas uma minoria dos "petistas de outubro" ainda declara preferir o partido.

Em suma, as evidências apresentadas nas últimas duas seções apontam para a possibilidade de que parte relevante da preferência pelo PT que se manifesta nas eleições presidenciais é apenas circunstancial. Esse petismo "eleitoral" é menos estável e menos efetivo do que o partidarismo daquele núcleo de petistas mais sofisticados que acompanha o partido com mais frequência. Evidentemente, a medida de estabilidade utilizada aqui apresenta limitações, visto que só capta a mudança entre dois pontos do tempo. Isso provavelmente simplifica os resultados e esconde matizes importantes. De todo modo, o formato de painel da pesquisa possibilitou testar hipóteses que ainda não haviam sido examinadas mais diretamente por meio de dados empíricos. Diante desses achados, é possível questionar a validade teórica de análises que veem a preferência partidária como uma causa ou um determinante que antecede o voto para presidente a partir do exame de correlações agregadas para todo o eleitorado.

\section{Conclusão}

O que se conclui com as análises acima é que parece equivocado supor que todo partidarismo manifestado no Brasil é partidarismo forte. As características do ambiente eleitoral brasileiro dificultam enormemente o estabelecimento de vínculos afetivos dos eleitores com os partidos, e essa dificuldade é ainda maior para os eleitores menos politicamente sofisticados (Castro, 1994; Kinzo, 2005). Nesse sentido, a interação entre a complexidade do ambiente eleitoral e a desigualdade de sofisticação política no eleitorado ajuda a entender o efeito maior ou menor que as preferências partidárias têm sobre o comportamento político em diferentes pontos do tempo e do espaço.

Se as análises acima são válidas, pode-se dizer que a correlação agregada entre partidarismo e voto no Brasil esconde o fato de que a segunda variável só é determinada pela primeira, de fato, para uma minoria politicamente sofisticada de eleitores. Certamente, a caracterização fornecida por Balbachevsky (1992) é válida para essa minoria de eleitores, mas não pode ser generalizada para todos os eleitores partidários no sistema político brasileiro. Esse raciocínio parece se aplicar a pouco mais da metade dos petistas que se manifesta em outubro, e não passaria de $20 \%$ do eleitorado brasileiro. 
Outra observação importante tem a ver com o fato de que as análises acima focalizam apenas os eleitores que declaram ter preferência pelo PT, e seria interessante saber até que ponto os achados do artigo também se aplicam aos eleitores dos demais partidos. Com relação a isso, o artigo de Samuels (2006, p. 19-20) fornece evidências de que a preferência pelos demais partidos brasileiros tenderia a ser ainda mais fraca e guiada por vínculos personalistas. Tendo como base as conclusões de Samuels, pode-se dizer que o presente artigo focaliza precisamente o subgrupo de eleitores entre os quais é mais provável encontrar orientações partidárias estáveis e efetivas. Nesse sentido, é provável que os achados acima sejam ainda menos otimistas com a inclusão de eleitores que se identificam com outros partidos.

Por fim, cabe enfatizar que as diferenças de estabilidade e efetividade das preferências partidárias de acordo com o nível de sofisticação política não denotam que eleitores menos sofisticados sejam irracionais ou mesmo que sejam exclusivamente culpados por isso. Ainda que seu comportamento apresente padrões menos previsíveis, o que os resultados das análises acima mostram é apenas que eles respondem menos aos partidos enquanto objetos do ambiente eleitoral. Além disso, mesmo quando um grupo de eleitores declara preferência por um partido, a desigualdade de sofisticação política tem efeito no sentido de que os menos sofisticados tendem a formar essa preferência com base em estímulos mais transitórios do ambiente eleitoral, e não em percepções quanto a questões políticas mais centrais que atravessam o sistema partidário. Para esse último grupo, ainda que a preferência partidária se manifeste nas pesquisas eleitorais, ela não é muito mais do que apenas uma resposta a uma pergunta. Como é baseada em estímulos passageiros, tal preferência tende a desaparecer mais facilmente e a não afetar outras preferências políticas importantes que o cidadão é chamado a manifestar (Zaller, 1992; Zaller e Feldman, 1992). Nesse sentido, a instabilidade e a falta de efetividade das preferências partidárias dos cidadãos menos sofisticados revelam justamente seu esforço para dar conta dos acontecimentos políticos à sua volta. Diante de um ambiente eleitoral complexo e da própria falta de habilidade em manusear as informações políticas que recebem, esses eleitores procuram responder aos partidos e candidatos conforme recebem incentivos positivos ou negativos para tanto. A manifestação um tanto errática de suas preferências apenas revela as dificuldades que o ambiente eleitoral complexo lhes impõe. 


\section{Referências}

BALBACHEVSKY, Elizabeth (1992). "Identidade partidária e instituições políticas no Brasil". Lua Nova, n. 26, p. 133-165.

BAKER, Frank (2001). The basics of item response theory. Baltimore: ERIC Clearinghouse on Assessment and Evaluation.

BAKER, Andy; AMES, Barry \& RENNÓ, Lucio (2006). "Social context and campaign volatility in new democracies: networks and neighborhoods in Brazil's 2002 elections". American Journal of Political Science, v. 50, n. 2, p. 382-399.

BARTELS, Larry (2000). "Partisanship and voting behavior, 1952-1996". American Journal of Political Science, v. 44, n. 1, p. 35-50.

BERRY, William; DEMERITT, Jacqueline \& ESAREY, Justin (2010). “Testing for interaction in binary logit and probit models: is a product term essential?” American Journal of Political Science, v. 54, n. 1, p. 248-266.

BIRNBAUM, Allan (1968). "Some latent trait models and their use in inferring an examinee's ability”, em LORD, Frederick M. \& NOVICK, Melvin R. (eds.). Statistical theories of mental test scores. Reading: Addison-Wesley.

BRADY, Henry \& SNIDERMAN, Paul (1985). "Attitude attribution: a group basis for political reasoning". The American Political Science Review, v. 79, n. 4, p. 1061-1078.

BRODY, Richard (1991). "Stability and change in party identification: presidential to off-years", em SNIDERMAN, Paul; BRODY, Richard \& TETLOCK, Philip. Reasoning and choice: explorations in political psychology. New York: Cambridge University Press.

CAMPBELL, Angus; GURIN, Gerald \& MILLER, Warren (1954). The voter decides. Evanston: Row, Peterson and Company.

CAMPBELL, Angus; CONVERSE, Philip; MILLER, Warren \& STOKES, Donald (1960). The American voter. New York: John Wiley.

CARREIRÃO, Yan de Souza (2007). "Relevant factors for the voting decision in the 2002 presidential election: an analysis of the ESEB (Brazilian Electoral Study) data”. Brazilian Political Science Review, v. 1, n. 1, p. 70-101.

CARREIRÃO, Yan de Souza \& KINZO, Maria D’alva (2004). "Partidos políticos, preferência partidária e decisão eleitoral no Brasil (1989/2002)”. Dados, v. 47, n. 1, p. 131-168.

CASTRO, Mônica M. M. (1994). Determinantes do comportamento eleitoral: a 
centralidade da sofisticação política. Tese (doutorado) em Ciência Política. Rio de Janeiro: Instituto Universitário de Pesquisas do Rio de Janeiro. CONVERSE, Philip (1969). "Of time and partisan stability". Comparative Political Studies, n. 2, p.139-171.

CRAIG, Stephen (1985). "The decline of partisanship in the United States: a reexamination of the neutrality hypothesis". Political Behavior, v. 7, n. 1, p. 57-78.

DALTON, Russell (2007). "Partisanship and party system institutionalization". Party Politics, v. 13, n. 2, p. 179-196.

DALTON, Russell \& WATTENBERG, Martin (2000). Parties without partisans: political change in advanced industrial democracies. Oxford: Oxford University Press.

DRUCKMAN, James (2001). "Using credible advice to overcome framing effects". The Journal of Law, Economics \& Organization, v. 17, n. 1, p. 62-82. FIORINA, Morris (1981). Retrospective voting in American national elections. New Haven: Yale University Press.

HOWELL, Susan (1986). "Candidates and attitudes: revisiting the question of causality”. The Journal of Politics, v. 48, n. 2, p. 450-464.

IMAI, Kosuke; KING, Gary \& LAU, Olivia (2008). “Toward a common framework for statistical analysis". Journal of Computational and Graphical Statistics, v. 17, n. 4, p. 892-913.

(2009). Zelig: everyone's statistical software. Disponível em: http:// gking.harvard.edu/zelig. Acessado em 16 mar 2010.

KAUFMANN, Karen; PETROCIK, John \& SHAWN, Daron (2008). Unconventional wisdom: myths and facts about American voters. Oxford: Oxford University Press.

KING, Gary; TOMZ, Michael \& WITTENBERG, Jason (2000). "Making the most of statistical analysis: improving interpretation and presentation". American Journal of Political Science, v. 44, n. 2, p. 341-355.

KINZO, Maria D’alva (2005). “Os partidos no eleitorado: percepções públicas e laços partidários no Brasil”. Revista Brasileira de Ciências Sociais, n. 57, p. $65-81$.

KROSNICK, Jon \& RAHN, Wendy (1994). “Attitude strength”. Encyclopedia of Human Behavior, n. 1, p. 279-289.

LAMOUNIER, Bolivar (1975). “Comportamento eleitoral em São Paulo: passado e presente”, em LAMOUNIER, Bolivar \& CARDOSO, Fernando 
Henrique (orgs.). Os partidos e as eleições no Brasil. Rio de Janeiro: Paz e Terra.

(1978). "Presidente Prudente: o crescimento da oposição num reduto arenista”, em REIS, Fábio (org.). Os partidos e o regime: a lógica do processo eleitoral brasileiro. São Paulo: Símbolo.

(1980). “O voto em São Paulo: 1970-1978”, em LAMOUNIER, Bolivar. Voto de desconfiança: eleições e mudança política no Brasil: 19701979. São Paulo: Vozes.

LAVAREDA, Antônio (1991). A democracia nas urnas: o processo partidário eleitoral brasileiro. Rio de Janeiro: Rio Fundo.

LAZARSFELD, Paul; BERELSON, Bernard \& GAUDET, Hazel (1965). The people's choice: how to voter makes up his mind in a presidential campaign. New York: Columbia University Press.

LUSKIN, Robert (1990). "Explaining political sophistication". Political Behavior, v. 12, n. 4, p. 331-361.

NEUMAN, W. Russell (1981). "Differentiation and integration: two dimensions of political thinking". The American Journal of Sociology, v. 86, n. 6, p. 1236-1268.

NICOLAU, Jairo (2007). "An analysis of the 2002 presidential elections using logistic regression”. Brazilian Political Science Review, v. 1, n. 1, p. 125-135.

OSTERLIND, Steven (1983). Test item bias. Newbury Park: Sage.

REIS, Fábio W. (1975). “As eleições em Minas Gerais”, em LAMOUNIER, Bolivar \& CARDOSO, Fernando Henrique (orgs.). Os partidos e as eleições no Brasil. Rio de Janeiro: Paz e Terra.

(1978). "Classe social e opção partidária: eleições de 1976 em Juiz de Fora”, em REIS, Fábio W. (org.). Os partidos e o regime: a lógica do processo eleitoral brasileiro. São Paulo: Símbolo.

(1983). "O eleitorado, os partidos e o regime autoritário brasileiro", em SORJ, Bernardo \& ALMEIDA, Maria Hermínia Tavares de (orgs.). Sociedade política no Brasil pós-64. São Paulo: Brasiliense.

SAMUELS, David (2006). "Sources of mass partisanship in Brazil". Latin American Politics and Society, v. 48, n. 2, p. 1-27.

WATTENBERG, Martin (1996). The decline of American political parties, 1952-1996. Cambridge: Harvard University Press.

ZALLER, John (1992). The nature and origins of mass opinion. New York: Cambridge University Press. 


\section{ZALLER, John \& FELDMAN, Stanley (1992). "A simple theory of survey response: answering questions versus revealing preferences". American Journal of Political Science, v. 36, n. 3, p. 579-616.}

\section{Resumo}

O artigo utiliza dados de pesquisa de opinião em painel coletados ao longo de 2002 em Caxias do Sul (RS) e Juiz de Fora (MG) para testar em que medida a preferência partidária é uma atitude estável e efetiva entre os eleitores brasileiros que a declaram. As análises focalizam os eleitores do Partido dos Trabalhadores. A questão que move o artigo é até que ponto a preferência partidária pode ser vista como uma causa do voto para presidente no Brasil. Duas perspectivas são contrastadas em busca da resposta para essa questão. A primeira defende que, ainda que restrita a uma parcela minoritária do eleitorado, a preferência partidária constitui uma atitude forte. Para a segunda perspectiva, a preferência partidária é, de maneira geral, uma atitude instável que emerge durante o período eleitoral, provavelmente em virtude da campanha e da identificação do eleitor com os candidatos. Os resultados das análises mostram que grande parte do petismo manifestado nas pesquisas de opinião em outubro se deve à saliência da eleição presidencial e tende a desaparecer posteriormente, além de ser menos importante para a escolha de candidatos para outros cargos em disputa. Além disso, esse petismo instável é mais comum entre eleitores menos politicamente envolvidos e sofisticados.

Palavras-chave: preferência partidária, voto, partidos, eleições.

\section{Abstract}

This article uses panel survey data from Caxias do Sul (RS) and Juiz de Fora (MG) in 2002 to assess to what extent partisanship constitutes a stable and effective political orientation for Brazilian voters. The analysis in the article focuses on respondents who support the Workers' Party. The main question is whether party identification can actually be considered a cause of vote choice in the Brazilian multi-party system. In order to answer this question, two competing perspectives are examined. The first perspective argues that, even though partisanship is restricted to a small proportion of the Brazilian electorate, it is a strong orientation among those voters who express it. The second perspective argues that partisanship is mostly an unstable orientation that acquires salience only during electoral periods, and due in large part to campaign effects and the influence of candidates. The results show that almost half of the party preferences that are reported in the electoral period are exclusively a result of the salience of the presidential election, and that partisan identification tends to disappear when the race is over. Moreover, unstable partisans tend to vote less frequently for their preferred party in elections than 
stable partisans. Finally, it is shown that unstable partisans tend to present lower levels of political involvement and sophistication than stable partisans.

Key words: party preference, voting behavior, parties, elections.

Recebido em 15 de novembro de 2011.

Aprovado em 31 de março de 2012. 